\title{
Application of MOHID platform to simulate the drift of cetaceans stranded in coastal regions. A case study in the Paulista coastline.
}

\author{
Aplicação da Plataforma MOHID na simulação da trajetória de carcaças de baleias em \\ regiões costeiras. Caso de estudo no litoral paulista.
}

Jader Lugon Junior ${ }^{1}$, Francine de Almeida Kalas², Pedro Paulo Gomes Watts Rodrigues $^{2}$, Manuela Juliano ${ }^{3}$, Hugo Gallo Neto ${ }^{4}$, José Luiz Jeveaux ${ }^{4}$, Antônio José da Silva Neto ${ }^{2}$

\section{ABSTRACT}

In this work it is simulated the trajectory of a beached whale sighted near Ilhabela region, in São Paulo coastline, Brazil, in November, 2017. The computational implementation was performed on the MOHID platform (HIDrodynamicsMOdel), using Water module. The downscaling technique was used to obtain local hydrodynamic currents at local scale. The validity of the model was considered satisfactory after comparing the results to satellite measurements of the sea surface temperature and also temperature and salinity profiles measured by ARGO buoys, attesting the purpose to use the model to simulate the trajectory of the cetacean specimen. The use of these technologies has great potential for researchers, since it allows the accompaniment of these organisms and avoids the stranding in tourist or densely populated regions, like Paulista region.

Keywords: MOHID platform. Hydrodynamic model. Lagrangiantrajectories. Cetaceans.

\section{RESUMO}

Neste trabalho é apresentado a simulação da trajetória de uma baleia encalhada na região de Ilhabela, litoral paulista, em novembro de 2017. A implementação computacional foi realizada na plataforma MOHID (HIDrodynamicsMOdel), utilizando o módulo água. A técnica de modelos encaixados foi utilizada para obtenção das correntes hidrodinâmicas nas escalas locais. A validação do modelo foi realizada comparando-se os resultados encontrados pelo MOHID com os valores de temperatura da superfície do mar obtidos por satélite pelo projeto MyOcean e também com os perfis de temperatura e salinidade na coluna d'água mensurados por bóias Argo. O uso dessas tecnologias tem grande potencial para pesquisadores uma vez que permite o acompanhamento de organismos, como os cetáceos, prevenindo o encalhe em regiões costeiras de grande atratividade turística ou densamente povoadas, como é o caso do litoral norte paulista.

Palavras-chave: Plataforma MOHID. Modelo hidrodinâmico. Trajetóriaslagrangianas. Cetáceos. 


\section{INTRODUCTION}

Specimens of cetaceans have been recorded on Brazilian coastline since the 17th century (ELLIS, 1969). The increase in the whale population on the coast of Brazil has been strengthened by actions to protect and preserve these organisms in Brazilian marine waters (BRASIL, 2008, p.6; among others). The Brazilian Institute of the Environment (IBAMA) has been working to expand these actions, actively participating in various national and international forums for the conservation of these organisms. The year 2001 was marked by the proposal to create the South Atlantic Whale Sanctuary, whose implementation has being discussed in the plenary sections of the International Whale Commission (IWC).

Whales are sighted regularly along the Brazilian coast from September to March, when the waters of the coast are warmed up and migration occurs, for procreation and in search of food (SICILIANO et al, 2004, p. 859;MOURA; SICILIANO, 2012, p. 5). In the coast of São Paulo, the main species sighted are humpback (Megapteranovaengliae) and bryde (Balaenoptera brydei)ones. Experts from the Argonauta Institute for Coastal and Marine Conservation, a non-governmental organization that acts in projects of environmental education and beaches monitoring, have been monitoring the sighting and stranding of whales on the Paulista coastline since 1998. The main natural factors cited in the literature for the occurrence of strandings in coastal regions are local oceanographic and topographical conditions, as water temperature, direction and speed of the wind and marine currents (SANTOS et al., 2010, p.124; PARENTE et al., 2017, p.36). In the case of stranding of dead animals, the Argonauta technical team uses appropriate management techniques to navigate to uninhabited regions, in order to avoid risks to navigation or associated with the presence of predators in the tourist beaches of this region (GALLO NETO et al., 2019, p. 2).

The use of computational models with a Lagrangian approach to simulate tracer trajectories has been widely applied by a range of software that allows the developer to define the characteristics of his simulation (DAGGEST et al, 2018, p.4). Several researches have been developed in this sense, involving the drift of tracers such as hydrocarbons (RODRIGUES \& MAIORINO, 2017, p.1; CAMPOS et al, 2017, p. 413), sediments (ALVAREZ et al, 2011, p.199; FRANZ et al, 2017, p. 673), marine litter (DECLERCK et al, 2019, p.1) and objects (NAM, KIM, 2018, p. 1), as well as the rescue of 
people (MATEUS et al, 2015; p.332) and organisms (PUTMAN, HE, 2013, p. 1) in the marine environment.

This study intends to evaluate the importance of the management of the Argonauta Institute action in the final destination of cetacean skeleton that strand near north coast of São Paulo. In this way, a simulation to follow the trajectory of a carcass of a Bryde specie, found near the Ilhabela region, was implemented computationally, considering that there was no management by Argonauta team of technicians.

The hydrodynamic model was implemented in MOHID Water computational platform, open source code, which was coded in ANSI FORTRAN 95, allowing the flow of information to be carried out by modules. Actually, MOHID Water has 40 modules that permits the integration of different tools that simulate a several process in water bodies, accounting for more than 240,000 lines of code.

\section{HYDRODYNAMIC SIMULATION}

Thethree-dimensional hydrodynamic model MOHID Water is applied to surface water bodies (oceans, estuaries and reservoirs) for solving the equations of continuity and momentum (Eqs.1-4) for incompressible fluids from the Boussinesq and hydrostatic approximations (RODRIGUES et al., 2012, p. 24 - 25). The turbulence is calculated according to the coefficients of diffusivity and viscosity $k-\varepsilon$ of the global ocean turbulence model (GOTM).

$$
\begin{aligned}
& \frac{\partial u_{i}}{\partial x_{i}}=0 \\
& \frac{\partial u_{1}}{\partial t}+\frac{\partial\left(u_{j} u_{1}\right)}{\partial x_{j}}=f u_{1}-g \frac{\rho_{\eta}}{\rho_{0}} \frac{\partial \eta}{\partial x_{1}}-\frac{1}{\rho_{0}} \frac{\partial p_{g}}{\partial x_{1}}-\frac{g}{\rho_{0}} \int_{s}^{\eta} \frac{\partial \rho^{r}}{\partial x_{1}} \partial x_{3}+\frac{\partial}{\partial x_{j}}\left(\vartheta \frac{\partial u_{1}}{\partial x_{j}}\right) \\
& \frac{\partial u_{z}}{\partial t}+\frac{\partial\left(u_{j} u_{2}\right)}{\partial x_{j}}=f u_{2}-g \frac{\rho_{\eta}}{\rho_{0}} \frac{\partial \eta}{\partial x_{2}}-\frac{1}{\rho_{0}} \frac{\partial p_{g}}{\partial x_{z}}-\frac{g}{\rho_{0}} \int_{s}^{\eta} \frac{\partial \rho^{r}}{\partial x_{2}} \partial x_{3}+\frac{\partial}{\partial x_{j}}\left(\vartheta \frac{\partial u_{2}}{\partial x_{j}}\right) \\
& \frac{\partial p}{\partial x_{s}}=-\rho g
\end{aligned}
$$

where $u_{i}$ are the velocity components in the Cartesian directions $x_{i} ; i=1,2,3 ; \eta$ is the elevation of free surface; $f$ is the Coriolis parameter; $\vartheta$ is the turbulent viscosity; $p_{s}$ is 
the atmospheric pressure; and $\rho$ is the reference density, $\rho$ ' is the specific mass anomaly and $\rho_{\eta}$ is the density at the free surface.

The spatial discretization obeys a finite volume methodology and temporal discretization is obtained with application of semi-implicit algorithms (ADI). Spatial discretization in MOHID Water is implemented in the "Geometry" module and allows the simultaneous selection of different types of coordinates (Figure 1).

Sigma-type coordinates, generally applied to barotropic models, are defined at the top of the domain and fit with bathymetry and water column variations. The Cartesian type coordinates, applied to baroclinic embedded models, are defined at the bottom of the domain, in layers from the hydrographic zero $(\mathrm{ZH})$ or fixed depth $(\mathrm{h})$. More information about spatial discretization is present in MOHID platform website (www.mohid.com).

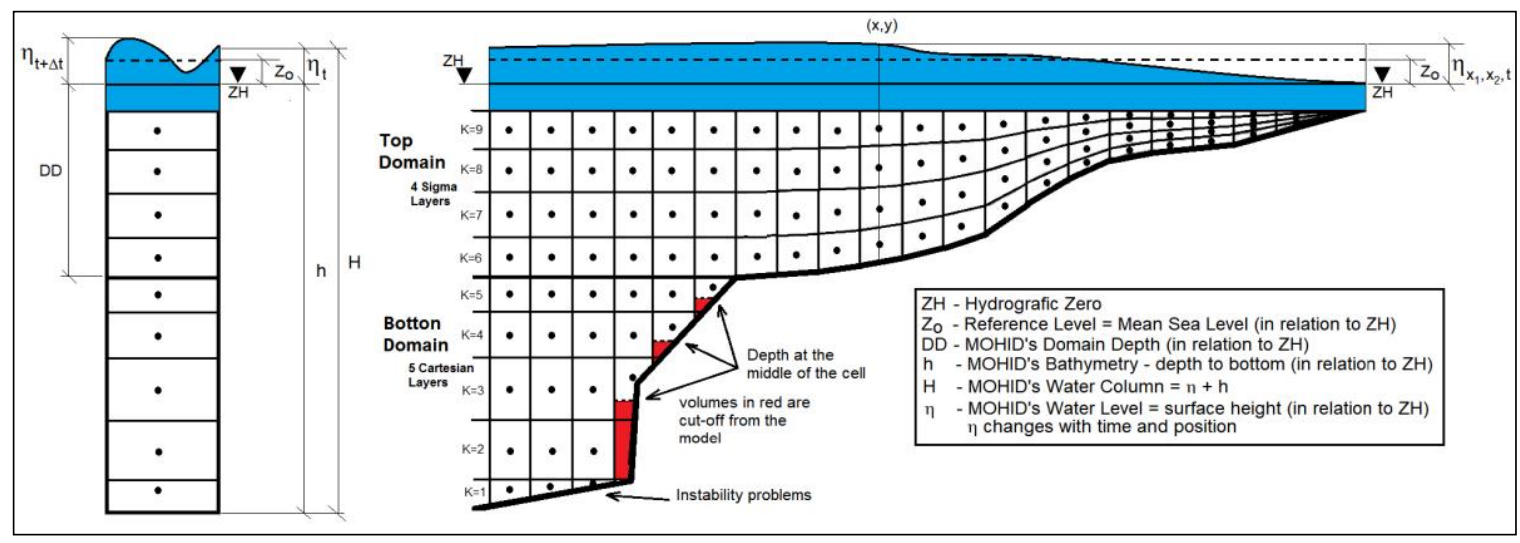

Figure 1. Spatial discretization in MOHID Water

The particle trajectory is calculated using Lagrangian module in MOHID, according to the field of currents coming from the hydrodynamic module, at each calculation instant. The displacement of the particles is affected by the mean flow velocity (Eq. 5), with the velocity of wind drift being included through a space-time constant.

$$
\frac{\partial x_{i}}{\partial t}=u_{i}\left(x_{i}, t\right)
$$

where $u_{i}$ represents the mean velocity and $x_{i}$ is the position in the domain.

The MOHID platform allows the use of several simultaneously nested models, in which the boundary conditions are provided to the sub-models from a general model. The forcing data used by the downscaling technique were: the tidal harmonic components from 
FES2012 (CÀRRERE et al., 2012, p.13.2), daily salinity, temperature and mean water level obtained from MyOcean (COPERNICUS, 2017) and meteorological information obtained from GFS (GFS, 2017).

\section{METODOLOGY}

\subsection{Study Area}

The Argonauta Institute, located in Ubatuba city, has been activated since 2010 with information about strandings and sightings of cetaceans on the north coast of São Paulo (São Sebastião, Ilhabela, Caraguatatuba and Ubatuba municipalities) (Figure 2), carrying out procedures to tow skeleton remains and seizure in uninhabited regions.

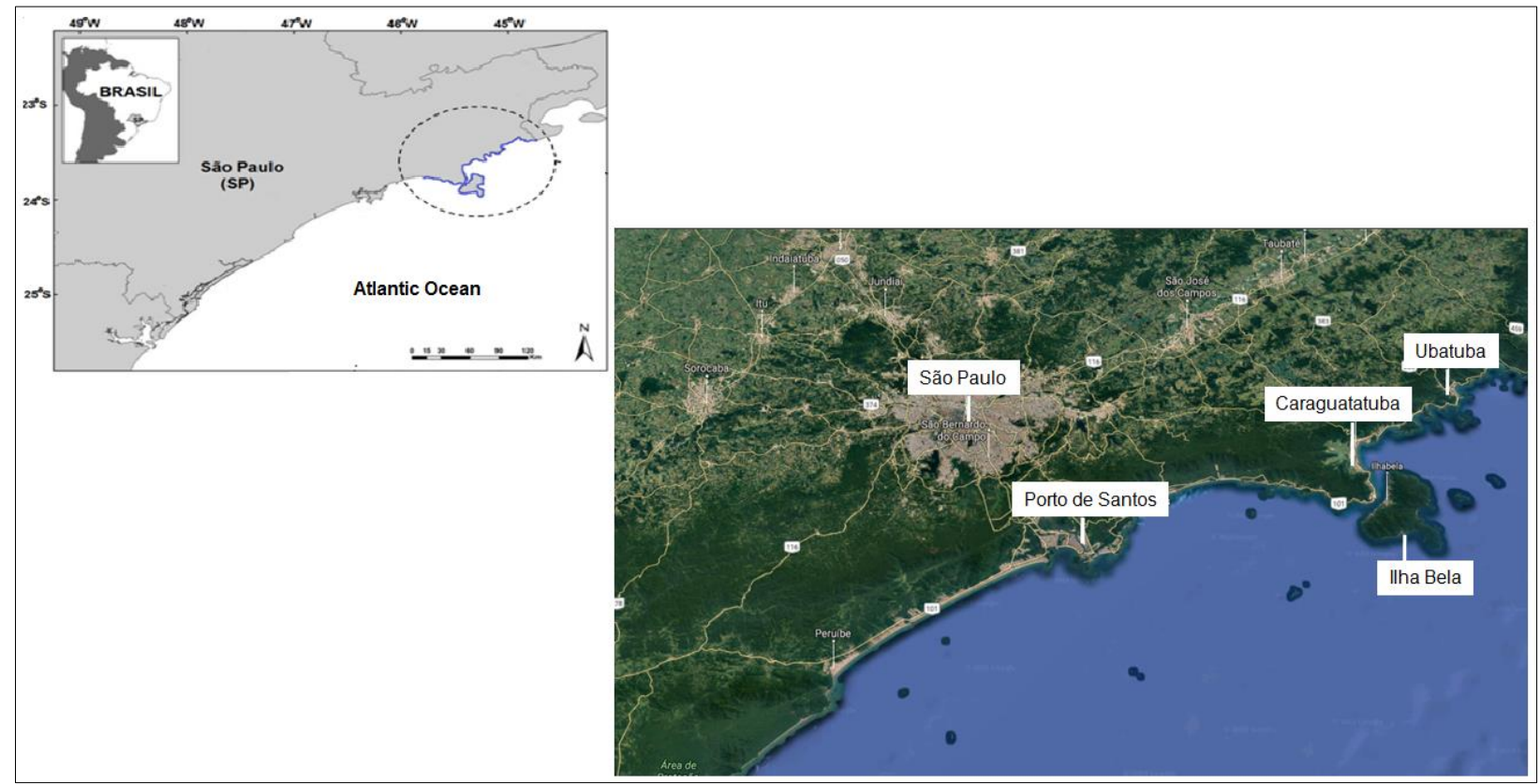

Figure 2. Study area - São Paulo north coastline

On 22th November, 2017, a skeleton of a Bryde (Balaenoptera brydel) whale was sighted in the vicinity of Curral beach, in Ilhabela. The displacement of this specimen was carried out, by the technical team of Argonauta Institute, to an uninhabited region, known as São Sebastião beach. Figure 3 shows the region that occurred the sighting and lashing of the beached whale. 


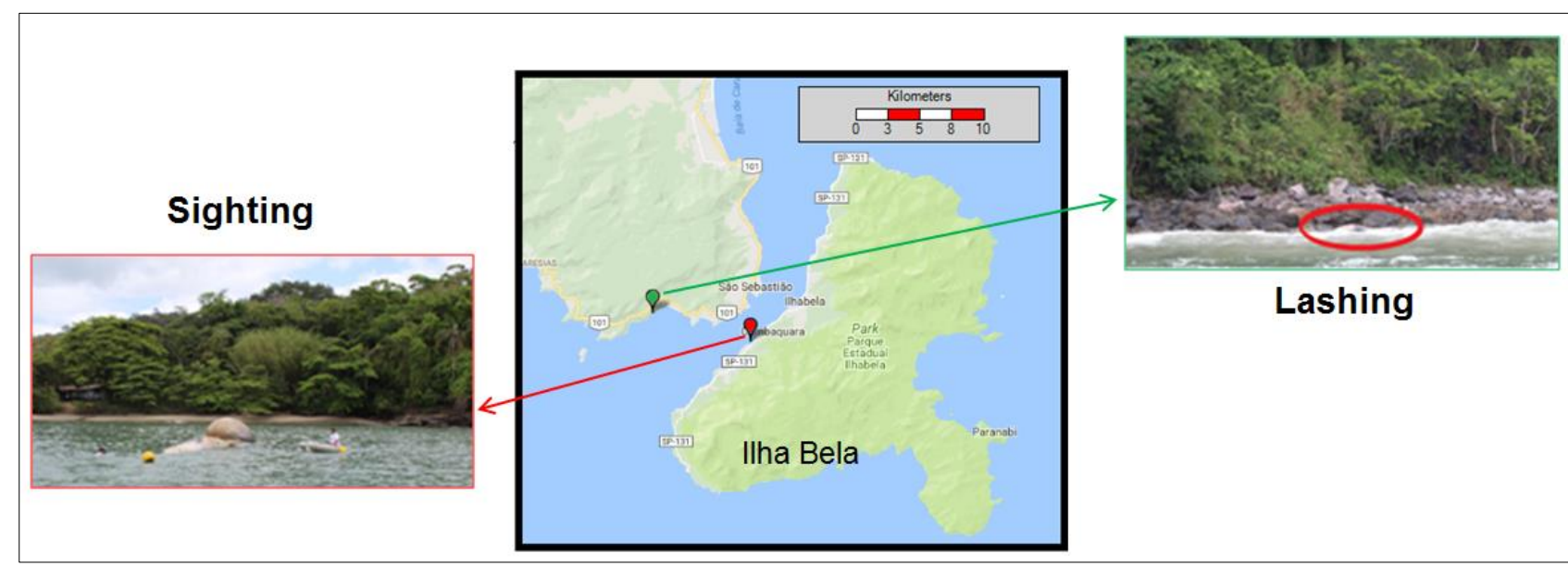

Figure 3. Area where the sighting occurred (red balloon) and lashing (green balloon) of the beached whale in llhabela region by Argonauta technical team.

The choice of the final site of anchoring of the cetacean skeleton by Argonauta team usually takes into account the absence of inhabitants, to avoid the contact with numerous parasites, as a source of diseases, and also prevent predators from approaching.

\subsection{Model Implementation}

The implementation of the hydrodynamic model in this work was performed according to the technique of downscaling, which philosophy allows to study in detail areas of small dimensions with a very fine mesh.

Four nested modelswere implemented in this work, which includes a 2D hydrodynamic formulation, South America (domain 1),implemented as general bartotropic model, and the 3D baroclinic formulation for the sub-modelsBrazil (domain 2), São Paulo (domain 3) and Ilhabela (domain 4). Figure 4 below shows the area covered and the bathymetry of each nested domain modeled. The batimetric data was obtained from GEBCO Grid Database (GEBCO, 2017). The MOHID spatial discretization at each domain is shown in Table 1. 


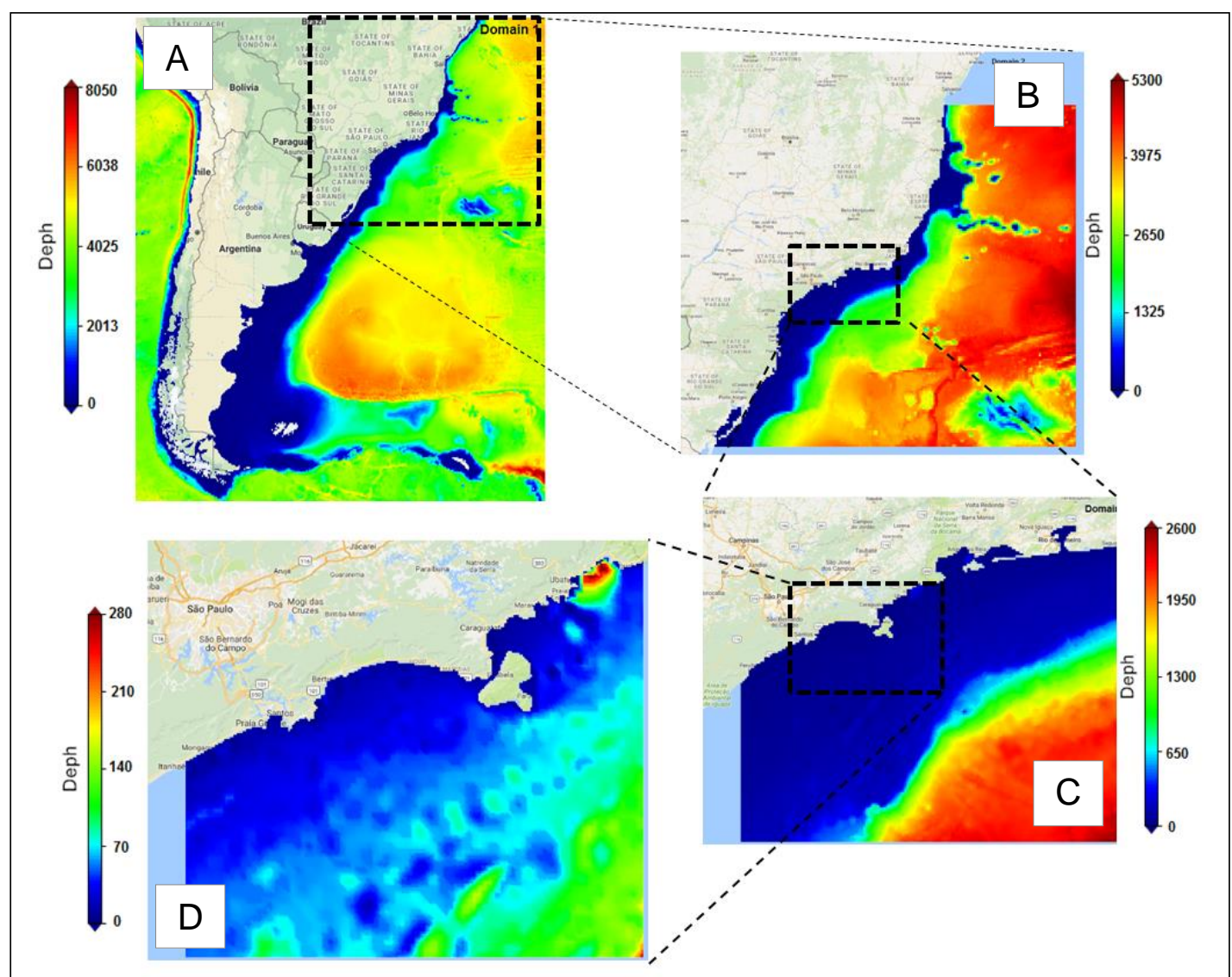

Figure 4.Area covered by each nested model. A - South America (domain 1); B - Brazil (domain 2); C Santos (domain 3); D - Ilha Bela (domain 4)

Table 1. MOHID spatial discretization

\begin{tabular}{ccccc}
\hline Level & Domain & \multicolumn{1}{c}{ Horizontal resolution } & Maximum Deph \\
\hline 1 & South America & $0.120^{\circ}$ & $12,000 \mathrm{~m}$ & $8050 \mathrm{~m}$ \\
2 & Brazil & $0.120^{\circ}$ & $12,000 \mathrm{~m}$ & $5300 \mathrm{~m}$ \\
3 & Santos & $0.024^{\circ}$ & $2,400 \mathrm{~m}$ & $2580 \mathrm{~m}$ \\
4 & Ilhabela & $0.008^{\circ}$ & $800 \mathrm{~m}$ & $280 \mathrm{~m}$ \\
\hline
\end{tabular}

The imposed open boundary conditions (OBC) in nested model differs at each hydrodynamic domain. The first level, number 1 , is forced with tide alone (there is no wind in "Atmosphere" module and "InterfaceWaterAir" module). From the second level to the last one, number 2 to 4, the models are nested 3D domains (e.g., including the density gradient effects) and the $\mathrm{OBC}$ are resolved by imposing a Flow Relaxation Scheme (FRS) that is similar to the one presented by (MARCHESIELLO et al., 2001, p. 5 - 7). The FRS was applied to temperature $(T)$, salinity $(S)$ and velocities $(u, v)$ (MARTINSEN; ENGEDAHL, 1987, p. 607) being combined with a radiation scheme from FLATHER (1976) for the barotropic mode. 
The hydrodynamic model implementation in MOHID is presented in follow schematic diagram (Figure 5). More detailed information about this procedure is available in the website of MOHID platform (MOHID, 2017).

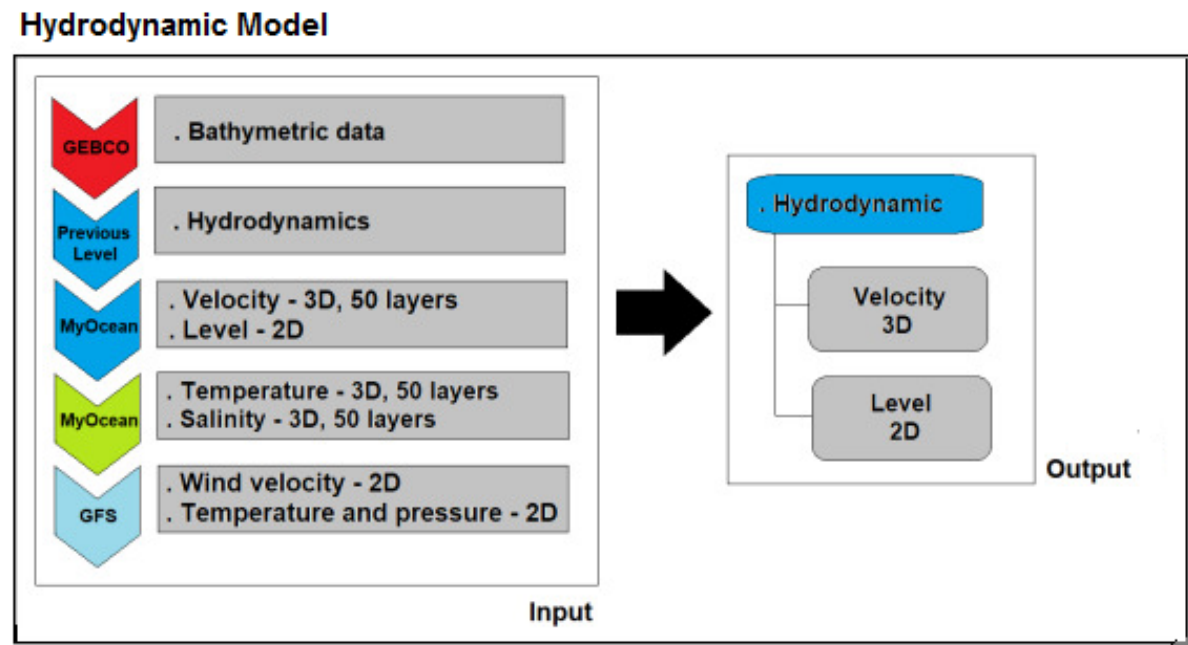

Figure 5. Schematic diagram of the hydrodynamic model.

\section{RESULTS AND DISCUSSION}

\subsection{Model Validation}

The validation of the hydrodynamic model, made in the Brazil domain, was performed through of the automatic statistical comparison, realized by a statistical tool in MOHID simulator, with 135,000 sea surface temperature (SST) data to satellite images of the GFS project (GFS, 2017). The results were satisfactory in relation to those obtained fromMOHID model, as can be seen in Figure 6. In the case of the validation of in-depth profiles, it was used 134,000 data of temperature and salinity obtained from 30 buoys of ARGO project (ARGO, 2017) available in Brazilian coast domain. The statistical evaluation of modeling results presented an excellent agreement with observed data, with $R$ analyses values of 0,91 for SST, 0,99 for temperature profile and 0,95 for salinity profile (Figure7). 


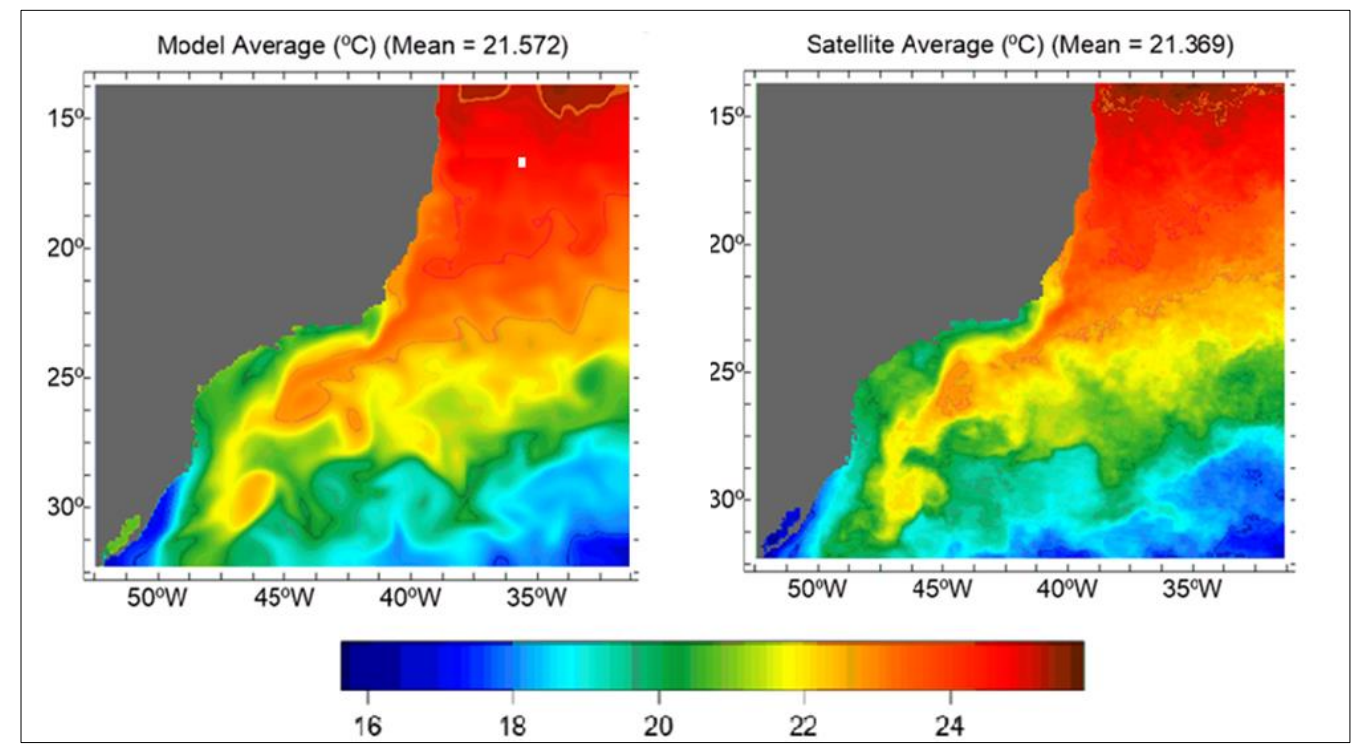

Figure 6. SST validation

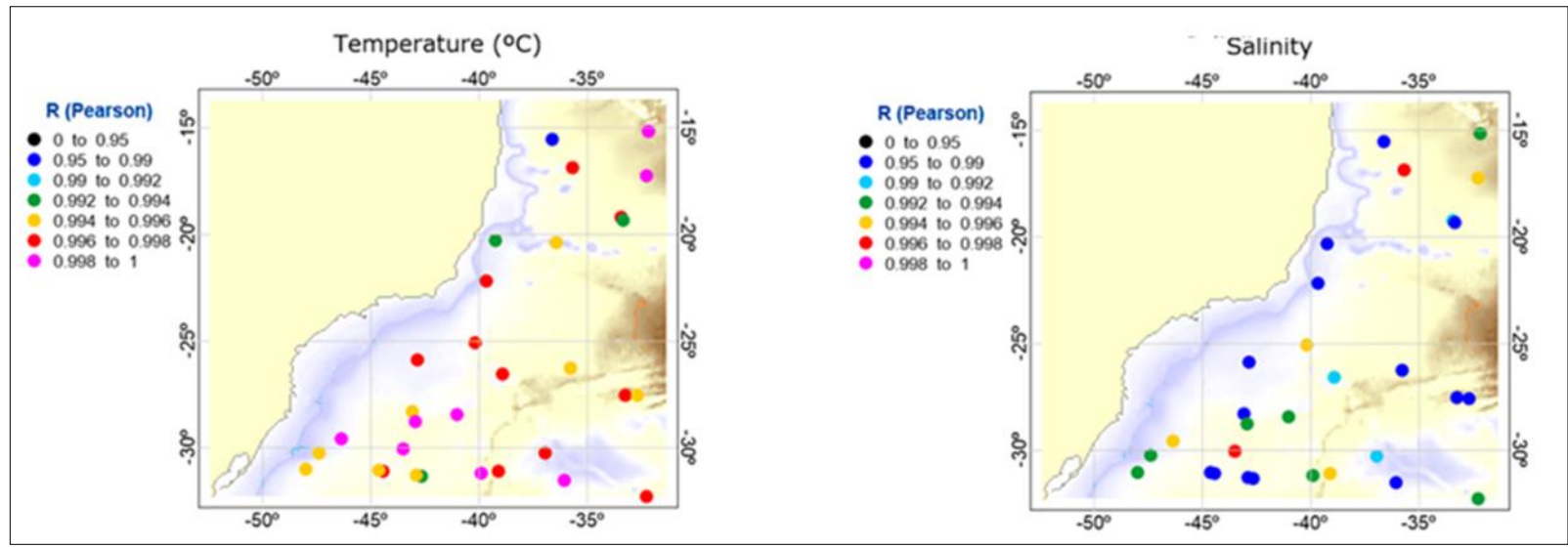

Figure 7. Temperature and salinity profile validation, showing Pearson analysis.

\subsection{Simulation of the Whale's Carcass Trajectory}

After the definition of the domain, initial and boundary conditions included, and hydrodynamic validation, the characteristics of the whale was adjusted in the Lagrangian module. The spatial evolution is computed integrating the velocities in the Cartesian directions $x$ and $y$.

The simulation of trajectory was based on the Argonauta whale report in 22th November, 2017, near São Paulo coastline, in front of Ilhabela region. Figure 8 shows the trajectory of the whale carcass simulated by MOHID if there was no human interference, only under the action of winds, waves and currents. According to the model estimative, the specimen would have been carried out to the Arrastão and São Franscisco beaches (points 6 and 7 in the map, respectively), a touristic and portuary region. 


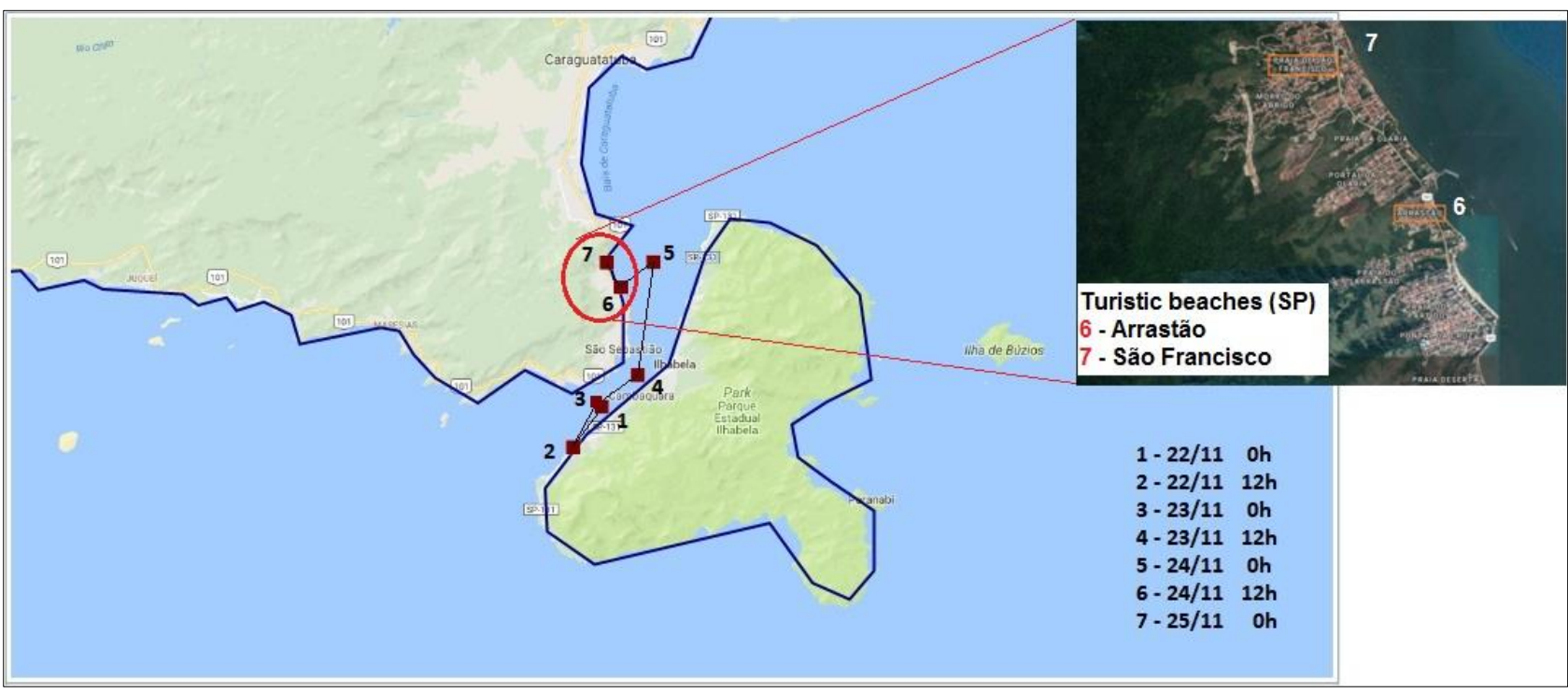

Figure 8. Simulation of the trajectory of the Bryde's carcass according MOHID implementation

\section{CONCLUSIONS}

The presence of a whale's carcass and its decomposition, especially in urbanized regions, can generate a serious public health problem. The decomposition of its skeleton generates some gases that can exude a foul odor, causing great economic losses in tourist areas and urban beaches. The removal can be laborious and costly, or even impossible, both for society and for the Public Authorities.

In spite of the great complexity of coastal systems, hydrodynamic models coupled to transport models can be able to reproduce and even predict the drift of cetaceans skeletons in such environments. Thus, the Lagrangian trajectory simulation of a whale' carcass can be an important monitoring and predictive tool that can support the strategy of its removal or reallocation, in order to avoid them toreach populated and touristic beaches.

\section{REFERENCES}

AlVAREZ, L. I.; CuADRADO, D. G.; PERILlO, G. M. E. Aplicación de un modelo de trazadores lagrangianos en Bahía Anegada, Argentina. Revista de Biologia Marina y Oceanografia. v. 46, n. 2, 2011, p. 199-206.

ARGO Argo Data System. In: Argo: part of the integrated global observation strategy. Available in <http://www.argo.ucsd.edu/>.Accessed in:December, 2017. 
BRASIL. Águas Jurisdicionais Marinhas Brasileiras como Santuário de Baleias e Golfinhos. Decreto 6.698/2008. DOU sec.1 n.246, p.6. Brasília. Brazil. 18 ${ }^{\text {th }}$ December, 2008.

CAMPOS, L.F.; PAIVA, P.M.; RODRIGUES, P.P.G. W. R.; FERREIRA, M. I.; LUGON JR, $J$. Disposal of waste from cementing operation from offshore oil and gas building. Ciencia e Natura, Santa Maria, vol. 39, n. 2, Mai/Aug 2017, p. 413-422.

CARRÈRE, L.; LYARD, F.; CANCET, M.; GUILLOT, A. \& ROBLOUT, L. FES2012: A new global tidal model taking advantage of nearly 20 years of altimetry.20 Years of Progress in Radar Altimetry, Venice, Italy.Sep. 2012, p.13.1-13.6.

COPERNICUS Marine Environment Monitoring Service.Available in $<$ http://marine.copernicus.eu/services-portfolio/access-toproducts/?option=com\_cswl\&task=results $>$ Accessed in Dec, 2017.

DAGGEST, K.; ROHRS, J.; BREIVIK, O.; ÅDLANDSVIK, B. OpenDrift v1.0: a generic framework for trajectory modeling. Geosci. Model Dev., v. 11, 2018, p. 1405-1420.

DECLERCK, A.; DELPEY, A. R.; FERRER, A.; BASURKO, O.C.; MADER, J.; LOUZAO, $M$. Transport of floating marine litter in the coastal area of the south-eastern Bay of Biscay: A Lagrangian approach using modeling and observations. Journal of Operational Oceanography, May 2019, p. 1-15.

\section{ELLIS, M. A baleia no Brasil colonial. São Paulo: Editora Melhoramentos, 1969. 235 p.}

FLATHER, R.A. A tidal model of the north-west European continental shelf. Memoires de la SocieteRoyale des Sciences de Liege, v. 6, n. 10, 1976, p. 141-164.

FRANZ, G. A. S.; DELPEY, M.T.; BRITO, D.; PINTO, L.; LEITAO, P.; NEVES, R. Modeling of sediment transport and morphological evolution under the combined action of waves and currents. Ocean Sci, v. 13, 2017, p. 6763 - 690

GALLO NETO, H.; CAMBA, D.; JEVEAUX, J. L.; BARBOSA, C. B. M. V.; ALBADEJO, M. C.; KALAS, F. A.; RODRIGUES, P. P. G. W.; LUGON JR, J.; SILVA NETO, A. Management strategies and computational modeling of cetaceans' carcasses in north coastline of São Paulo, Brazil.In: IX Congresso sobre Planejamento e Gestão das Zonas Costeiras dos Países de Expressão Portuguesa. Lisboa, Portugal. $14-16^{\text {th }}$ May, 2019.

GEBCO Gridded bathymetry data. In: General Bathymetric Chart of Oceans. Available in:<https://www.gebco.net/data \_and _products/gridded $\_b a t h y m e t r y \ d d a t a>$. Accessed in December, 2017.

GFS GFS Analysis. In: Global Forecast System. Available in: $<$ https://www.ncdc.noaa.gov/data-access/model-data/model-datasets/global-forcastsystem-gfs $>$. Accessed in December, 2017.

MATEUS, M.; PINTO, L.; LEITAO, P. Evaluating the predictive skills of ocean circulation models in tracking the drift of a human body: A case study. Australian Journal of Forensic Sciences, vo. 47, n. 3, Oct 2015, p. 332-331. 
MARCHESIELLO, P.; McWILLIAMS, J.C. \& SHCHEPETKIN, A. Open boundary conditions for long-term integration of regional oceanic models. Ocean Modeling. Nova Scotia, Canada. v. 3, n. 1-2. 2001, p. 1-20.

MARTINSEN, E. A.; ENGDAHL, H. Implementation and testing of a lateral boundary scheme as an open boundary condition in a barotropic model.Coastal Engineering, Amsterdam.v.11, n. 5 - 6, December, 1987. p. 603 - 627.

MOHID. MOHID Water - Hydrodynamic, Water Quality, Particle Tracking, Sediment Dynamics. In: MOHID Water Modeling System. Available in: < http://www.mohid.com/pages/models/mohidwater/mohid_water_home.shtml>. Accessed in December, 2017.

MOURA, J.F.; SICILIANO, S. Stranding pattern of Bryde's whales along the southeastern coast of Brazil.Marine Biodiversity Records, 5, 1-7. 2012.

PUMAN, N. F.; HE, R. Tracking the long-distance dispersal of marine organisms: sensitivity to ocean model resolution. J. R. Soc. Interface, vol. 10, n. 81, Apr 2013, p. 111.http://doi.org/10.1098/rsif.2012.0979.

RODRIGUES, P.; MAIORINO, J. R. Um estudo de acidentes de derramamento de óleo em São Sebastião utilizando o programa MOHID. In: X Congresso Brasileiro de Planejamento Energético, Gramado, RS - Brazil. Sep 2016.

RODRIGUES, P.P.G.W.; NASCIMENTO, E.C., LUGON JR, J. (Org.)Descrição do MOHID. Campos dos Goytacazes (RJ): Essentiaeditora, 2012.

SANTOS, M.C.O.; SICILIANO, S.; VICENTE, A.F.C.; ALVARENGA, F.S.; ZAMPIROLLI, E.; SOUZA, S.P. \&MARANHO, A.Cetaceanrecordsalong São Paulo Coast, SotheasternBrazil.Brazilian Journal of Oceanography. São Paulo, Brasil. v. 58, n. 2, Apr/Jun 2010, p. 123-142.

SICILIANO S., SANTOS M.C.O., VICENTE A.F.C., ALVARENGA F.S., ZAMPIROLLI E., BRITO JR J.L., AZEVEDO A.F. and PIZZORNO J.L. A. Strandings and feeding records of Bryde's whales (Balaenoptera edeni) in southeastern Brazil. Journal of the Marine Biological Association of the United Kingdom. United Kingdom.v. 84, n. 4, August, 2004. p. 857-859.

PARENTE, C.L.; MOURA, J.; SECCO, H. \& Di BENEDITTO, A.P.M. Diversidade e distribuição de cetáceos na área de influência das atividades de E\&P na Bacia de Campos. In: Reis, E.C., Curbelo-Fernandez, M. P. eds. Mamiferos, quelonios e aves: Caracterização ambiental regional da Bacia de Campos, Atlântico Sudoeste. Rio de Janeiro: Elisevier. Habitats. 2017, p. 35-61.

NAM, Y-W; KIM, Y-H. Prediction of drifter trajectory using evolutionary computation. Discrete Dynamics in Nature and Society, 2018, p 1-15. 